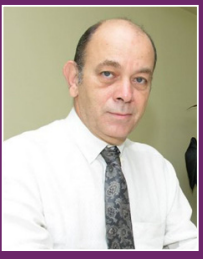

Douglas Wagner Franco, Ph. D. in analytical chemistry in 1972 at Universidade de São Paulo (USP) Brazil. Postdoctoral research at: 1 . Stanford University - USA, Prof. Henry Taube (1976); 2. University of California at Santa Barbara - USA, Prof. Peter C. Ford (1982); 3 . Institute de Recherches sur la Catalyse - France, Prof. Igo Katchenko (1984); 4. Università degl Studi di Parma - Italia, Prof. J. Paolo Chiusoli (1985); 5. York University - Canada, Prof. Alfred B. P. Lever (1990). Full Professor at University of São Paulo since 1986. Current research interest addresses the chemisty of ruthenium Current research interest addresses the chemistry of ruthenium nitrosyl complexes, and the chemistry of the Brazilian sugar can spirit (cachaça),

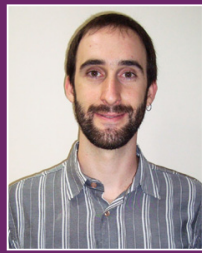

Antonio Carlos Roveda Jr took his degree (B.Sc.) in Chemistry (B) Universidade Estadual Paulista (Unesp) Unversiade Estadual Paulista (Unesp) in 2008 and his M.Sc. degree at Instituto de Química de São Carlos (IQSC) Universidade de São Paulo, in 2011. Presently is a graduate student (Ph.D.) in inorganic and analytical chemistry in inorganic and analytical chemistry His research materials for nitric oxide release.

\section{Nitric Oxide Releasing-dendrimers: an Overview}

\author{
Antonio Carlos Roveda Júnior¹, Douglas Wagner Franco ${ }^{1, *}$
}

${ }^{1}$ Institute of Chemistry of São Carlos, University of São Paulo, São Carlos, SP, Brazil

Platforms able to storage, release or scavenge NO in a controlled and specific manner is interesting for biological applications. Among the possible matrices for these purposes, dendrimers are excellent candidates for that. These molecules have been used as drug delivery systems and exhibit interesting properties, like the possibility to perform chemical modifications on dendrimers surface, the capacity of storage high concentrations of compounds of interest in the same molecule and the ability to improve the solubility and the biocompatibility of the compounds bonded to it. This review emphasizes the recent progress in the development and in the biological applications of different NO-releasing dendrimers and the nitric oxide release pathways in these compounds.

Uniterms: Dendrimer. Nitric oxide. Nitrosyl complexes. Diazeniumdiolate. Nitrosothiol.

Plataformas capazes de armazenar, liberar ou capturar NO de forma controlada e específica são de grande interesse tendo-se em vista aplicações biológicas. Dentre as possíveis matrizes que podem ser utilizadas para esse fim, os dendrímeros são excelentes candidatos. Essas moléculas têm sido empregadas em sistemas para o transporte de fármacos $\mathrm{e}$ apresentam propriedades interessantes tais como a possibilidade de modificações químicas em sua superfície, a capacidade de estocar altas concentrações de compostos de interesse em uma só molécula e a possibilidade de aumentar a solubilidade e a biocompatibilidade dos compostos a eles ligados. Esta revisão enfatiza os recentes avanços no desenvolvimento e nas aplicações biológicas de diferentes dendrímeros liberadores de $\mathrm{NO}$ e a forma em que o óxido nítrico é liberado nesses compostos.

Unitermos: Dendrímero. Óxido nítrico. Nitrosilo complexos. Diazeniodiolato. Nitrosotiol.

\section{INTRODUCTION}

Chemical, biological (Fukuto et al., 2012; Toledo, Augusto, 2012) and medical aspects of nitric oxide (NO) have been subject of great interest since the discovery that mammalian cells are able to synthesize it (Palmer, Ashton, Moncada, 1988; Pagliaro, 2003; Pacher, Beckman, Liaudet, 2007). This uncharged diatomic molecule is generated endogenously by three nitric oxide synthases (NOS) enzymes - endothelial NOS, neuronal NOS and inducible NOS - which catalyses the conversion of L-arginine to L-citrulline, yielding NO (Palmer, Ashton, Moncada, 1988; Ignarro, 1990; Zweier et al., 1995; Zhou, Zhu, 2009). Nitric oxide, a small molecule signaling agent (Fukuto et al., 2012), is associated with many biological processes (Toledo, Augusto, 2012) as vasodilatation (Furchgott, Zawadzki, 1980; Hu et al., 2003; Yetik-Anacak, Catravas, 2006; Pacher, Beckman, Liaudet, 2007), immune response (Bogdan, 2001; Bogdan, Röllinghoff, Diefenbach, 2000;
*Correspondence: D. W. Franco. Grupo de Química Analítica e Inorganica, Instituto de Química de São Carlos, Universidade de São Paulo. Av. Trabalhador São-Carlense, 400, 13560-970 São Carlos - SP, Brasil. E-mail: douglas@iqsc.usp.br 
Karpuzoglu, Ahmed, 2006), as regulator of the central and peripheral nervous system (Bredt, Hwang, Snyder, 1990; Garthwaite, 1991, 1995; Moncada, Palmer, Higgs 1991; Steinert, Chernova, Forsythe, 2010), angiogenesis and muscle contractility (Reid, 2001; Stamler, Meissner, 2001).

Due to the properties outlined above, an exogenous NO deliver is a potential therapeutic agent, inasmuch deficiencies in NO biosynthesis are related to some diseases (Baylis, 2008; Luiking, Engelen, Deutz, 2010). NO can be administered in gaseous form (respiratory route) in specific cases (Serafim et al., 2012), but this compound is known to react with a wide number of molecules (proteins, thiols, heme proteins, metals and others) and also can be oxidized in solution to $\mathrm{NO}_{2}$ by $\mathrm{O}_{2}$ (Fukuto et al., 2012; Toledo, Augusto, 2012). In addition, the NO lifetime in biological media varies from $10 \mathrm{~ms}$ to $1 \mathrm{sec}$ (Thomas et al., 2001; Flores-Santana et al., 2009). Furthermore local lack or excess of NO can be deleterious for biological systems. Therefore, strategies to produce stable NO carriers systems have been developed, being much of the work focused on the synthesis of nitric oxide donors (NO-donors) (Wang et al., 2002; Serafim et al., 2012) or scavengers (Fricker et al., 1997; Davies et al., 1997).

There are some representative chemical classes of NO-donors (Figure 1), as $S$-nitrosothiols (RSNOs), diazeniumdiolates (NONOates), organic nitrates and nitrites, and metal nitrosyl complexes, which were recently reviewed (Miller, Megson, 2007; Keefer, 2011; Tfouni et al., 2012; Serafim et al., 2012).

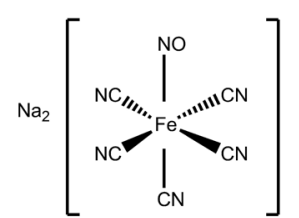

Sodium nitroprusside

(a)

S-nitroso-N-acetyl-penicillamine

(c)

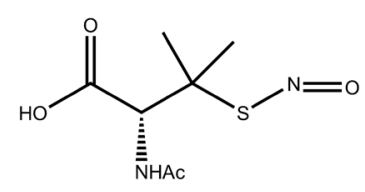

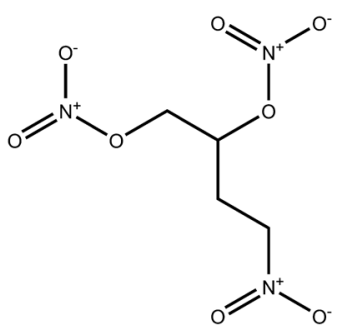

Glyceryl trinitrate (nitroglycerine)

(b)

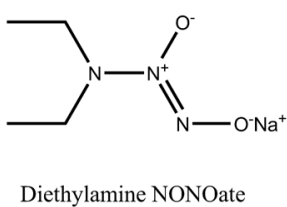

(d)
FIGURE 1 - Representative NO-donors: (a) metal nitrosyl, (b) organic nitrates, (c) S-nitrosothiols and (d) diazeniumdiolates.

Most of synthesized NO-releasing compounds have been used to help in understanding the physiologic aspects related to NO and to describe its therapeutic properties.
This last topic includes as examples the protection of myocardium against ischemia/reperfusion injuries (Chan, 2002; Webb et al., 2004; Schulz, Kelm, Heusch, 2004), toxicity toward cancer cells (Osti et al., 2012; Serafim et al., 2012), trypanocidal and leishmanicidal activities (Silva et al., 2007, 2009; Pereira et al., 2010; Guedes et al., 2010; Tfouni et al., 2012).

A reasonable volume of the current research have been focused on attaching NO releasing compounds to different platforms (Eroy-Reveles, Mascharak, 2010; Tfouni et al., 2010; Seabra, Durán, 2010; Riccio, Schoenfisch, 2012; Jen et al., 2012), as nanoparticles (Friedman et al., 2008; Seabra, Durán, 2010), silica gel (Zanichelli, Sernaglia, Franco, 2006; Doro, Rodrigues-Filho, Tfouni, 2007), xerogels and dendrimers (Stasko, Schoenfisch, 2006; Stasko, Fischer, Schoenfisch, 2008; Benini, McGarvey, Franco, 2008; Lu et al., 2011). These strategies aimed to improve NO-donors stability (Lu et al., 2011), promote a high payload of nitric oxide on a single platform (Stasko, Schoenfisch, 2006; Stasko, Fischer, Schoenfisch, 2008) and achieve specific targets (Taite, West, 2006).

In this context, next topics deal specifically with functionalized dendrimers, tailored for NO delivery and their possible applications.

\section{Dendrimers as a platform for NO transport}

Dendrimers are molecules of the dendritic materials group, which is also composed by dendronized and hyperbranched polymers, dendrons and dandrigrafts (Carlmark et al., 2009; Astruc, Boisselier, Ornelas, 2010). The main difference between dendrimers and dendrons regarding to the other dendritic polymers is related to their shape: dendrimers and dendrons are perfectly branched (Figure 2).

The concept of dendrimer-like compound was first described by Vögtle and coworkers (Buhleier, Wehner,

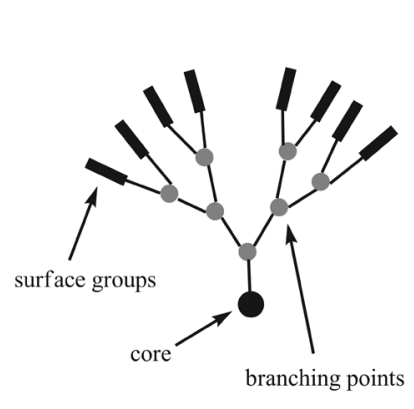

(A)

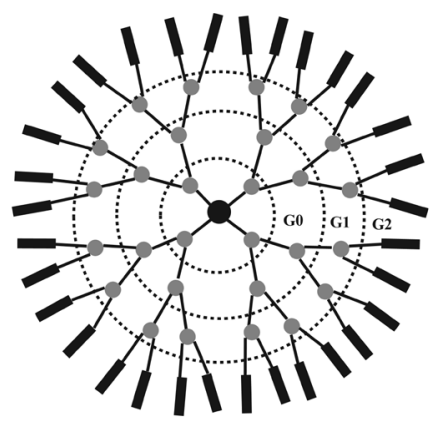

(B)
FIGURE 2 - Schematic picture of dendrons (A) and dendrimer (B). $\mathrm{Gn}(\mathrm{n}=0-2)$ represent dendrimer generations: generation 0 to 2 . 
Vögtle, 1978), who synthesized polypropyleneimine (PPI), employing branching trough repetitive growth approach. The first dendrimer synthesis was carried out independently by two groups of researchers: Tomalia and coworkers (1985) and Newkome and coworkers (1985), whose "baptize" their molecules as "starburst polymer" and "arborol", respectively. Dendrimers are generally described as hyperbranched molecules, with a well defined structure, possessing three main architectural components (Figure 2B): core, interior layers (radially branched) which define dendrimers generations and end-groups (surface or exterior) (Tomalia et al., 1985).

One of the key features related to dendrimers is the possibility of tailoring its surface through chemical modifications, and their conjugation with molecules or ions of interest (Astruc, Boisselier, Ornelas, 2010; Archut et al., 1998; Vögtle et al., 1999). Major applications are related to the drug delivery systems development (Gillies, Fréchet, 2005; Medina, El-Sayed, 2009; Nanjwade et al., 2009; Wijagkanalan, Kawakami, Hashida, 2011; Sun et al., 2012), solubility (Devarakonda, Hill, Villiers, 2004) and biocompatibility improvements (reduce toxicity) (Duncan, Izzo, 2005; Sadekar, Ghandehari, 2010; Ciolkowski et al., 2012), magnetic resonance image (MRI) contrast (Wiener et al., 1994; Margerum et al., 1997; Kobayashi et al., 2003; Kojima et al., 2011; Tang et al., 2012), targeted drug delivery (Yang et al., 2009; Menjoge et al., 2011) and gene delivery (Dufès, Uchegbu, Schätzlein, 2005; Kim et al., 2007; Mintzer, Simanek, 2009; Shcharbin, Klajnert, Bryszewska, 2009; Nam et al., 2012).

The most common dendrimers (Newkome, Shreiner, 2008; Mintzer, Grinstaff, 2011) are polyamidoamine (PAMAM), polyamide, poly(L-lysine) (PLL), polypropylenimine (PPI) and PEG-polyester types, being most of them commercially available.

Together with other types of matrices (Tfouni et al., 2010; Seabra, Durán, 2010; Saraiva et al., 2011; Riccio, Schoenfisch, 2012), dendrimers have been used as NOreleasing carriers platforms (Taite, West, 2006; Stasko, Schoenfisch, 2006; Stasko, Fischer, Schoenfisch, 2008; Benini, McGarvey, Franco, 2008; Lu et al., 2011). One of the advantages of the NO-donors dendrimers over others NO carriers systems is their ability of storage high concentrations of nitric oxide per unit of drug carrier. For example Stasko (Stasko, Schoenfisch, 2006) synthesized polypropylenimine (PPI) dendrimers of generations 3 and 5 conjugated with diazeniumdiolates (Figure 3 and Table I, compounds 1-7). The highest NO storage capac-

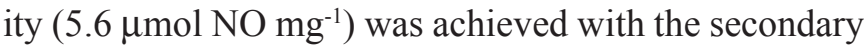
amine dendrimer 1 (DAB-PO-64/NO), followed by 6 (3.4 $\left.\mu \mathrm{mol} \mathrm{NO} \mathrm{mg}^{-1}\right)$ and $7\left(3.2 \mu \mathrm{mol} \mathrm{NO} \mathrm{mg}^{-1}\right)$, which were more stable than the ones containing primary amines $(4,5)$ and amides $(\mathbf{2}, \mathbf{3})$ (Stasko, Schoenfisch, 2006). Syntheses of diazeniumdiolate-dendrimers (1-7) were performed using high pressure of NO gas (5 atm) in basic solution to convert primary $(4,5)$, secondary amines $(\mathbf{1}, \mathbf{6}$ and $\mathbf{7})$ and amides $(\mathbf{2}, \mathbf{3})$ to diazeniumdiolates (Stasko, Schoenfisch, 2006). Secondary amines $(\mathbf{1}, \mathbf{6}, \mathbf{7})$ provided better conversion to diazeniumdiolates than primary amines $(4,5)$ and amides $(\mathbf{2}, \mathbf{3})$, as shown in Table I.

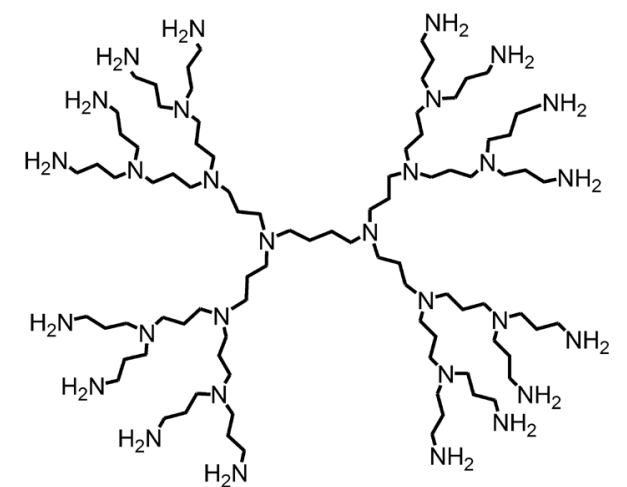

(A)

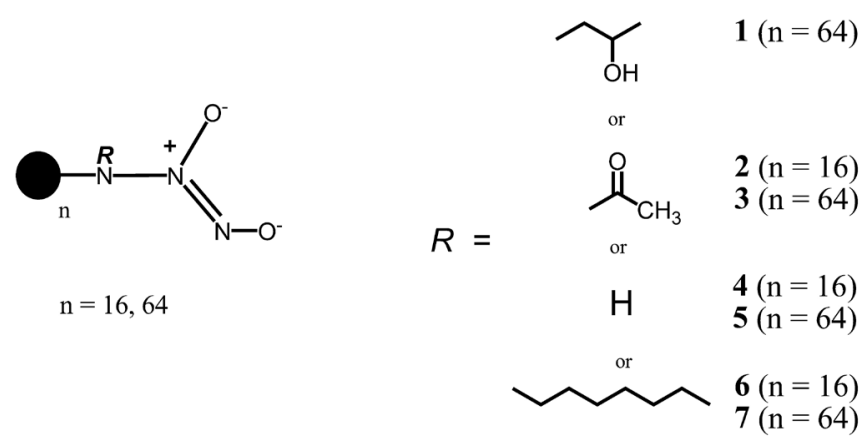

(B)

FIGURE 3 - Structure of (A) PPI dendrimer generation 3 and (B) PPI diazeniumdiolates (adapted from Stasko, Schoenfisch, 2006).

Also, PAMAM dendrimers were used as NO-releasing carriers. Stasko (Stasko, Fischer, Schoenfisch, 2008) synthesized two types of PAMAM dendrimer generation 4 , with $S$-nitroso- $N$-acetyl-L-cysteine (NACysNO) or Snitrosothiol- $N$-acetyl-D,L-penicillamine (SNAP) groups respectively attached to its surface (Figure 4 and Table I, compounds 8 and 9 , respectively). The capacity of nitric oxide storage of the two above $S$-nitrosothiol dendrimers was

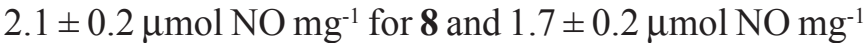
for 9 (Stasko, Fischer, Schoenfisch, 2008).

Taite and West (2006) have synthesized a poly(ethyleneglycol)-lysine (PEG-lys) dendrimer in which multiple diazeniumdiolate NO-donors were generated by 
TABLE I - General properties of NO-releasing dendrimers

\begin{tabular}{|c|c|c|c|c|c|c|}
\hline $\begin{array}{l}\text { NO-releasing } \\
\text { dendrimer }\end{array}$ & $\begin{array}{l}\text { Class of } \\
\text { NO donor }\end{array}$ & $\begin{array}{l}\text { NO-release } \\
\text { mechanism }\end{array}$ & $\begin{array}{c}\mathrm{t}_{1 / 2}(\mathrm{~min}) \\
\text { (half-life of NO } \\
\text { release) }\end{array}$ & $\begin{array}{l}\text { Number of } \\
\text { dendrimer } \\
\text { superficial } \\
\text { groups }\end{array}$ & $\begin{array}{l}\% \text { of } \mathrm{NO} \\
\text { conjugated } \\
\text { on the } \\
\text { dendrimer } \\
\text { surface }\end{array}$ & References \\
\hline DAB-PO-64/NO (1) & & $\begin{array}{l}\text { Spontaneous in } \\
\text { physiologic } \\
\text { condition }\end{array}$ & 28 & 64 & $47^{\mathrm{a}}$ & $\begin{array}{c}\text { (Stasko, } \\
\text { Schoenfisch, } \\
\text { 2006) }\end{array}$ \\
\hline DAB-Ac-64/NO (3) & & & 2.5 & 64 & $<0.2^{\mathrm{a}}$ & \\
\hline DAB-Am-16/NO (4) & Diazeniumdiolate & & 12 & 16 & $2.3^{\mathrm{a}}$ & \\
\hline DAB-Am-64/NO (5) & & & 29 & 64 & $3.9^{\mathrm{a}}$ & \\
\hline DAB-C7-16/NO (6) & & & 77 & 16 & $38^{\mathrm{a}}$ & \\
\hline DAB-C7-64/NO (7) & & & 86 & 64 & $36^{\mathrm{a}}$ & \\
\hline G0/RuNO (11) & $\begin{array}{c}\text { Metal-nitrosyl } \\
\text { complex } \\
\text { (ruthenium) }\end{array}$ & $\begin{array}{c}\text { Triggered by } \\
\text { chemical reduction } \\
\text { or light irradiation }\end{array}$ & $4.12-6.08^{f}$ & 4 & 100 & $\begin{array}{l}\text { (Benini, McGarvey, } \\
\text { Franco, 2008) }\end{array}$ \\
\hline G2/RuNO (12) & & & $3.98-8.25^{\mathrm{f}}$ & 16 & 75 & \\
\hline G3/RuNO (13) & & & ND & 32 & 90.6 & \\
\hline a-8-NO G2-PPI-ACN-NO (14) & Diazeniumdiolate & $\begin{array}{l}\text { Spontaneous in } \\
\text { physiologic } \\
\text { condition }\end{array}$ & 288.6 & 8 & $26.1^{\mathrm{a}}$ & (Lu et al., 2011) \\
\hline b-32-NO G4-PPI-PEG-NO (20) & & & 50.4 & 32 & $40.3^{\mathrm{a}}$ & \\
\hline b-64-NO G5-PPI-PEG-NO (21) & & & 73.2 & 64 & $34.6^{\mathrm{a}}$ & \\
\hline c-8-NO G2-PPI-PO-NO (22) & & & 18 & 8 & $22.7^{\mathrm{a}}$ & \\
\hline c-16-NO G3-PPI-PO-NO (23) & & & 37.2 & 16 & $26.2^{\mathrm{a}}$ & \\
\hline c-32-NO G4-PPI-PO-NO (24) & & & 46.8 & 32 & $27.3^{\mathrm{a}}$ & \\
\hline c-64-NO G5-PPI-PO-NO (25)* & Diazeniumdiolate & & 63.6 & 64 & $32.1^{\mathrm{a}}$ & \\
\hline d-8-NO G2-PPI-SO-NO (26) & & & 88.2 & 8 & $12.2^{\mathrm{a}}$ & \\
\hline d-16-NO G3-PPI-SO-NO (27) & & & 58.2 & 16 & $10.3^{\mathrm{a}}$ & \\
\hline d-32-NO G4-PPI-SO-NO (28) & & & 85.8 & 32 & $13.6^{\mathrm{a}}$ & \\
\hline d-64-NO G5-PPI-SO-NO (29) & & & 97.2 & 64 & $14.5^{\mathrm{a}}$ & \\
\hline e-8-NO G2-PPI-ED-NO (30) & & & 48.6 & 8 & $24.2^{\mathrm{a}}$ & \\
\hline e-16-NO G3-PPI-ED-NO (31) & & & 102.6 & 16 & $21.1^{\mathrm{a}}$ & \\
\hline e-32-NO G4-PPI-ED-NO (32) & & & 80.4 & 32 & $19.9^{\mathrm{a}}$ & \\
\hline e-64-NO G5-PPI-ED-NO (33) & & & 112.8 & 64 & $24.7^{\text {a }}$ & \\
\hline
\end{tabular}

${ }^{a}$ values based on the conversion efficiency of amine or amide precursor to diazeniumdiolates. ${ }^{\mathrm{b}}$ depending on the trigger type (Stasko, Fischer, Schoenfisch, 2008). ${ }^{\mathrm{c}}$ number of thiol (NAP)/dendrimer estimated by ${ }^{1} \mathrm{H}$ NMR (the original PAMAM dendrimer has 64 end groups) (Stasko, Fischer,

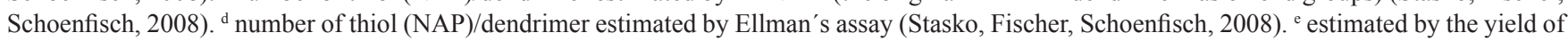
NO storage efficiency (Stasko, Fischer, Schoenfisch, 2008). ${ }^{\mathrm{f}}$ estimated from the $k_{\mathrm{obs}}$ values in different $\mathrm{pH} .{ }^{*}$ similar structure of compound $\mathbf{1}$. 


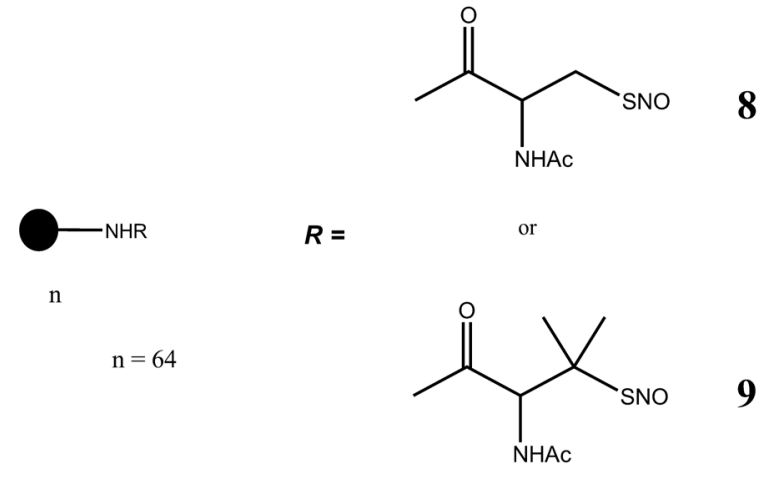

FIGURE 4 - Representation of PAMAM dendrimer with $S$-nitrosothiols (adapted from Stasko, Fischer, Schoenfisch, 2008).

the reaction of PEG-lys with $\mathrm{NO}$ gas (Table I, compound 10). This reaction converted $\sim 83 \pm 9 \%$ of amines in diazeniumdiolate NO-donors.

Benini, McGarvey and Franco (2008) have functionalized PAMAM dendrimers of generation 0,2 and 3 with the complex $\mathrm{K}[\mathrm{Ru}(\mathrm{edta}) \mathrm{Cl}]$. The functionalization was performed through a peptide bond between one of the carboxylate arms of the edta ligand and the superficial amines of dendrimers. This anchored chloro complex in aqueous solution yields the respective aquo species $\left[\mathrm{Ru}(\text { edta }) \mathrm{H}_{2} \mathrm{O}\right]^{-}$attached to the dendrimer surface. The reaction of this system with $\mathrm{NO}$ gas $(6 \mathrm{~h})$ yielded the $\mathrm{NO}$ analogous species [Ru(edta)NO], which remain anchored on PAMAM (Figure 5 and Table I, compounds 11-13). The percentage of superficial groups of PAMAM functionalized with ruthenium complexes were $100 \%$ for $\mathrm{G} 0,75 \%$ for G2 and 90.6\% for G3 (Benini, McGarvey, Franco, 2008). According to the reported data (Benini, McGarvey, Franco, 2008), compound $\mathbf{1 3}$ was able to storage $\sim 1.4$

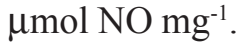

In addition, PAMAM dendrimer functionalized with $\left[\mathrm{Ru}(\text { edta }) \mathrm{H}_{2} \mathrm{O}\right]^{-}$can be used as nitric oxide scavenger, once $\left[\mathrm{Ru}(\mathrm{edta}) \mathrm{H}_{2} \mathrm{O}\right]^{-}$reacts with $\mathrm{NO}$ to produce $\left[\mathrm{Ru}(\right.$ edta $) \mathrm{NO}^{-}$at the second order rate constant of $\sim 2 \times 10^{7} \mathrm{M}^{-1} \mathrm{~s}^{-1}$ in phosphate buffer at $\mathrm{pH}=7.4$ and $7.3{ }^{\circ} \mathrm{C}$ (Davies et al., 1997; Wanat et al., 2002). NO scavengers were proposed as therapeutic agents for septic shock treatment (Davies et al., 1997, Fricker et al., 1997; Cameron et al., 2003), and dendrimers functionalized with [Ru(edta) $\mathrm{H}_{2} \mathrm{O}^{-}$could also be used for this purpose (Benini, McGarvey, Franco, 2008).

Lu et al. (2011) synthesized a series of amine PPI dendrimers (generation 2-5) functionalized with different surface groups (acrylonitrile $=\mathrm{ACN}$, propylene oxide $=$ $\mathrm{PO}$, styrene oxide $=\mathrm{SO}$ or poly $($ ethylene glyclol $)$ methyl ether acrylate $=$ PEG and 1,2-epoxy-9-decene $=$ ED). The

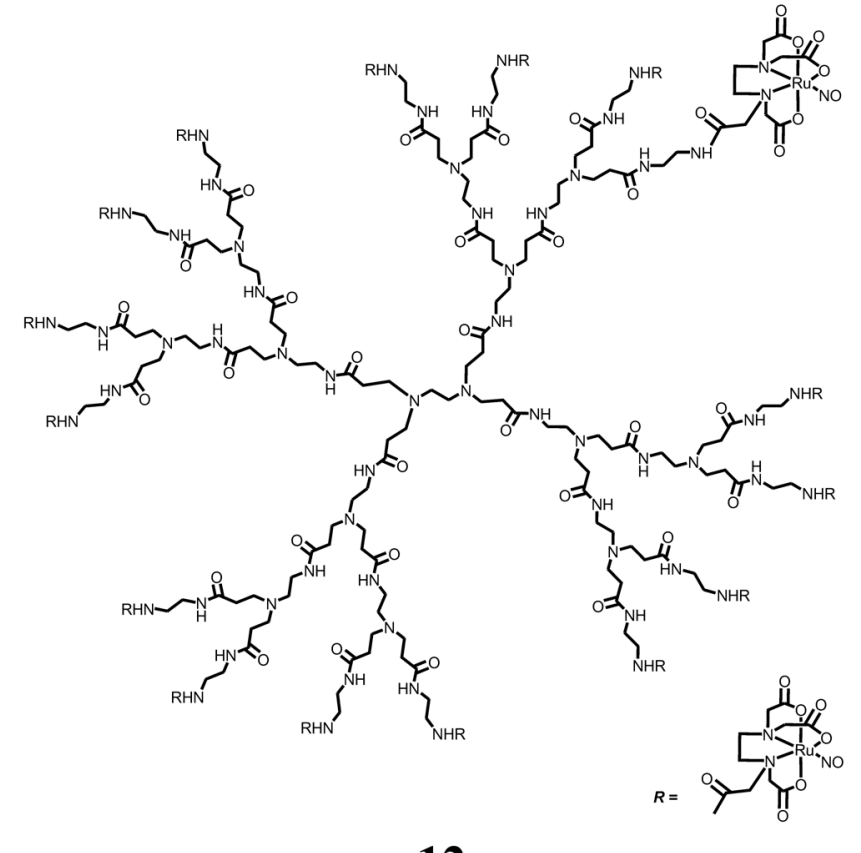

12

FIGURE 5 - PAMAM dendrimer generation 2 (G2/RuNO) functionalized with [Ru(edta)NO]. (Benini, McGarvey, Franco, 2008).

authors reacted these compounds with $\mathrm{NO}$ gas (10 atm of NO in a methanolic sodium methoxide solution) to produce the respective diazeniumdiolates on the resulting secondary amine G2-G5 PPI (Figure 6, Table I, compounds 14-33). The NO storage capacity of compounds $14-33$ was in the range of $0.9-3.8 \mu \mathrm{mol} \mathrm{NO} \mathrm{mg}^{-1}(\mathrm{Lu}$ et al., 2011), showing how dendrimer surface modifications influence the diazeniumdiolate properties (stability/release of NO).

Following a similar approach, Sun et al. (2012) functionalized PPI dendrimers of generation 2 and 5 with $\mathrm{PEG}, \mathrm{PO}$ or SO, and then reacted the products with $\mathrm{NO}$ gas (10 atm, in sodium methoxide solution in methanol) to obtain compounds of similar structure of $\mathbf{1 8}$ and $\mathbf{2 1}$ for PEG, $\mathbf{2 2}$ and $\mathbf{2 5}$ for PO and $\mathbf{2 6}$ and $\mathbf{2 9}$ for the SO PPI functionalized dendrimer (Figure 6). The NO storage capacity of

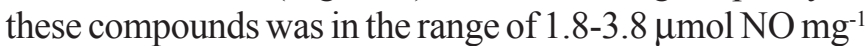
and the conversion efficiency of amines into diazeniumdiolates, between 19-35\% (Sun et al., 2012). Antibacterial activity of these compounds was tested against Grampositive and Gram-negative pathogenic bacteria (Sun et al., 2012), and it will be discussed in next sections.

\section{NO-donors dendrimers: mechanism of nitric oxide release}

One of the main differences observed among the NO-releasing dendrimers is their nitric oxide release 


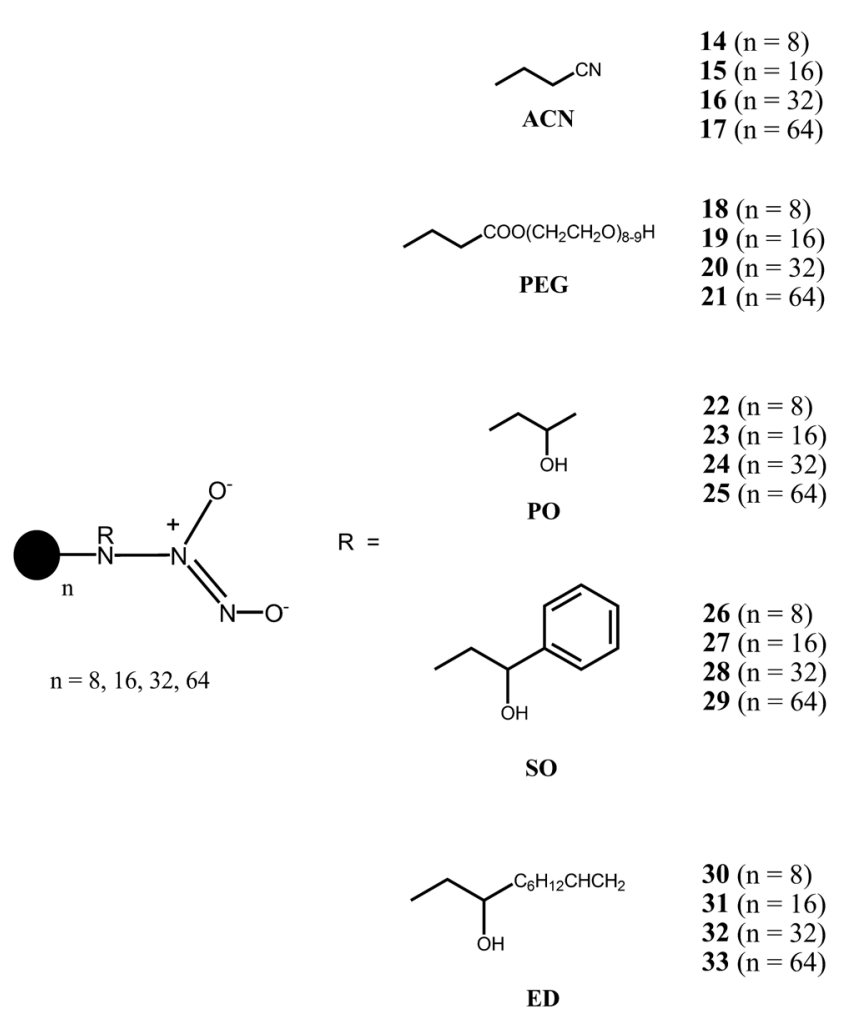

FIGURE 6 - Schematic representation of PPI dendrimer functionalized with different ligands and diazeniumdiolates (adapted from Lu et al., 2011; Sun, et al., 2012).

mechanism (see Table I). All diazeniumdiolate derivative dendrimers $(\mathbf{1 - 7 , 1 0 , 1 4 - 3 3}$ on Table I) release NO spontaneously under physiological conditions $\left(\mathrm{pH} 7.4,37^{\circ} \mathrm{C}\right)$, yielding two moles of NO per mole of diazeniumdiolate (Figure 7) (Davies et al., 2001; Hrabie, Keefer, 2002; Keefer, 2011).

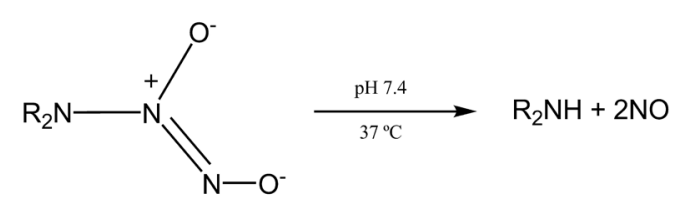

FIGURE 7 - NO release from diazeniumdiolate under physiological conditions.

Nitric oxide release in these dendrimer-diazeniumdiolates derivatives occurs through a hydrolytic degradation mechanism, initiated by protonation at the amine nitrogen (Davies et al., 2001; Hrabie, Keefer, 2002; Keefer, 2011). Compound 1 and 7 (Figure 3 ) were able to maintain the sustained-release of NO for more than $16 \mathrm{~h}$, followed by $6(\sim 14 \mathrm{~h})$, being these values the longest observed among analogous compounds (dendrimers 2-5) and small alkyl diazeniumdiolates (Stasko, Schoenfisch, 2006). The great increase on the NO release duration time, in comparison with small alkyl diazeniumdiolates, was attributed to the dendritic effect (Stasko, Schoenfisch, 2006), which resulted in an enhancement on the diazeniumdiolate stability. This effect was also correlated with the increase in the NO release half-life $\left(t_{1 / 2}\right)$ of NO-releasing dendrimers in comparison to the structural equivalent small molecules (Stasko, Schoenfisch, 2006).

In the other series of diazeniumdiolate PPI dendrimers (14-33, Figure 6), compounds 14-17 released NO for $\sim 25 \mathrm{~h}, \mathbf{1 8 - 2 1}$ for $\sim 21 \mathrm{~h}, \mathbf{2 2 - 2 5}$ for $\sim 22 \mathrm{~h}, \mathbf{2 6 - 2 9}$ for $\sim 17 \mathrm{~h}$ and 30-33 for $\sim 22 \mathrm{~h}$ (Lu et al., 2011). For compounds 1433, the NO release kinetics presented a wide range of $\mathrm{t}_{1 / 2}$ values, which varied from 18 to $293 \mathrm{~min}$ (Table 1). This broad range of values for $t_{1 / 2}$ was explained based on the dendrimers exterior modifications. Faster NO release (in general) observed for compounds 18-25 in comparison to others of this class (14-17 and 26-33) was attributed to the presence of PEG (18-21) or PO (22-25) groups on the dendrimers surface (Figure 6), which are hydrophilic and consequently facilitate the diazeniumdiolate degradation and the NO release (Lu et al., 2011). This explanation was consistent with the measured $t_{1 / 2}$ values for NO release from compounds 26-33, which have more hydrophobic surface groups at the exterior of dendrimer (SO or ED, Figure 6), thus resulting in higher $\mathrm{t}_{1 / 2}$ values than the ones observed for compounds 18-25.

It is interesting to note that despite the foregoing, the longest $t_{1 / 2}$ values for NO release in the series of diazeniumdiolate PPI dendrimers were observed for the compounds 14-17, which have a hydrophilic cyano group on the dendrimer surface. According to the authors (Lu et al., 2011), cationic groups on the neighboring of diazeniumdiolates are responsible for the additional stabilization of this class of NO-donors, thus increasing the $t_{1 / 2}$ values for NO release.

Also, Taite and West (2006) have synthesized another diazeniumdiolate dendrimer (10) that release NO for over 60 days period under physiological conditions, with the majority of the release occurring within the first 10 days.

According to Stasko, Fischer, Schoenfisch (2008) $S$-nitrosothiol (RSNO) derivative dendrimers $(\mathbf{8 , 9})$ are able to release nitric oxide by two main pathways (Figure 8): (A) transition metal-mediated catalytic decomposition, based on $\mathrm{Cu}^{+} / \mathrm{Cu}^{2+}$ redox couple and (B) photo-initiated decomposition. In the last pathway, irradiation of compounds 8 and 9 using a broad-spectrum white light resulted in homolytic cleavage of the $S-N$ bond, generating a thiyl radical (RS') and also liberating NO (Stasko, Fischer, Schoenfisch, 2008). 


$$
\begin{aligned}
& \text { RSNO } \stackrel{\mathrm{Cu}^{+}}{\longrightarrow} \mathrm{RS}^{-}+\bullet \mathrm{NO}+\mathrm{Cu}^{2+} \stackrel{\mathrm{RS}^{-}}{\longrightarrow} \mathrm{RSSR}+\mathrm{Cu}^{+} \\
& \mathrm{RSNO} \stackrel{\boldsymbol{h} v}{\longrightarrow} \mathrm{RS}{ }^{\bullet} \cdot \mathrm{NO} \stackrel{\mathrm{RSNO}}{\longrightarrow} \mathrm{RSSR}+{ }^{\bullet} \mathrm{NO}
\end{aligned}
$$

FIGURE 8 - General mechanism of nitrosothiol decomposition and NO release, (A) copper-mediated and (B) photo-initiated (adapted from Stasko, Fischer, Schoenfisch, 2008).

The rate constant for NO release was dependent on the structure of the nitrosothiol (SNAP or NACysNO) and on the NO release triggers (copper or light). This resulted in $\mathrm{t}_{1 / 2}$ values for $\mathrm{NO}$ dissociation in the range of 7-106 min for 8 and 1.5-2.3 min for 9 when triggered by copper ( 0.2 , 0.6 or $1 \mathrm{mM}$ of $\mathrm{Cu}^{2+}$ ), and 49-97 $\mathrm{min}$ for 8 and 34-200 min for 9 when triggered by light (60, 100 or 200 W) (Stasko, Fischer, Schoenfisch, 2008).

PAMAM dendrimers functionalized with ruthenium NO-donors (11-13) release nitric oxide after one-electron reduction, following a pathway similar to the other ruthenium nitrosyl complexes (Borges et al., 1998; Gomes et al., 1998; Tfouni et al., 2003; Carlos et al., 2004; Toledo et al., 2002, 2004; Metzker, Cardoso, Franco, 2013). According to Benini, McGarvey and Franco (2008) the reaction of compounds 11-13 with $\mathrm{Eu}$ (II) liberates NO (Figure 9), similarly to the analogous free ruthenium nitrosyl complexes (not attached on PAMAM): the nitrosyl ligand $\left(\mathrm{NO}^{+}\right)$is first reduced to $\mathrm{NO}^{0}$ and then dissociates from the ruthenium coordination sphere (Benini, McGarvey, Franco, 2008). Dissociation is the reaction rate determining step.

$$
\mathrm{Gx} / \mathrm{RuNO}^{+} \underset{\mathrm{H}_{2} \mathrm{O}}{\stackrel{\mathrm{Eu}(\mathrm{II})}{\longrightarrow}} \mathrm{Gx} / \mathrm{RuH}_{2} \mathrm{O}+\mathrm{NO}
$$

FIGURE 9 - Nitric oxide release from ruthenium nitrosyl dendrimer (Benini, McGarvey, Franco, 2008).

It is interesting to highlight that the chemical properties of ruthenium nitrosyl complexes were not altered after their attachment to the PAMAM dendrimers (Benini, McGarvey, Franco, 2008). The potential for the nitrosyl reduction $\left(\mathrm{NO}^{+} / \mathrm{NO}^{\circ}\right)$ in the compounds 11-13 was around $-0.32 \mathrm{~V}$ vs SCE (saturated calomel electrode), values which are very close to the ones measured for the complex $\left[\mathrm{Ru}(\text { edta)NO}]^{-}(-0.34 \mathrm{~V}\right.$ vs SCE). These redox potentials are accessible for the reducing agents as NADH, NADPH and cysteine present in biological media, thus enabling the in vivo delivery of $\mathrm{NO}$ from these metal nitrosyls. Also, the rate constants for NO release $\left(k_{-\mathrm{NO}}\right)$ in compounds $\mathbf{1 1}$ and 12 after one-electron reduction were in the range of 1.9$2.9 \times 10^{-3} \mathrm{~s}^{-1}$, which is in agreement with the previously reported (Zanichelli et al., 2004) $k_{-\mathrm{NO}}$ value of $2.1 \pm 0.4 \mathrm{x}$ $10^{-3} \mathrm{~s}^{-1}$ for [Ru(Hedta)NO] $\left(\mathrm{pH} 1.0,25^{\circ} \mathrm{C}\right)$. Compounds $\mathbf{1 1}$ and 12 showed $t_{1 / 2}$ values for $\mathrm{NO}$ release (after one electron reduction) in the range of 4.0-8.2 min (Table I) (Benini, McGarvey, Franco, 2008), which is in agreement with $t_{1 / 2}$ data for NO release for [Ru(Hedta)NO], that is $\sim 5.5 \mathrm{~min}$ (Zanichelli et al., 2004).

All together, the general features of the nitric oxide release mechanisms for all NO-donors presented above (diazeniumdiolates, $S$-nitrosothiol and metal nitrosyl complexes) were maintained when these compounds were attached to dendrimers.

\section{Applications of NO-releasing dendrimers}

Most of NO-releasing dendrimers discussed above were tested in different biological assays (Taite, West, 2006; Benini, McGarvey, Franco, 2008; Stasko, Fischer, Schoenfisch, 2008; Johnson et al., 2010; Sun et al., 2012). Stasko, Fischer and Schoenfisch (2008) described the ability of $S$-nitrosothiol derivative dendrimer 9 in the inhibition of thrombin-mediated platelet aggregation. According to the authors, the mechanism occurs via transnitrosation (Hogg, 2000; Walsh et al., 2007; Bell, Shah, Gordge, 2007; Stasko, Fischer, Schoenfisch, 2008), a process in which a nitrosothiol transfers the nitroso group to a free thiol (present in proteins on the platelet surface). Compound 9 inhibited platelet aggregation regardless of nitrosothiol (SNAP) concentration $(100,50$ or $25 \mathrm{mM})$, and at $25 \mathrm{mM}$ led to a reduction of $62 \%$ in the aggregation compared to $17 \%$ for $25 \mathrm{mM}$ of the analogous small molecule (similar $S$-nitrosothiol SNAP - not attached on dendrimer). Best results for 9 in comparison to the "free" SNAP were attributed by the authors to the increase on the $S$-nitrosothiols local concentration during the transnitrosation process, due to the anchoring of the dendrimer on the cell surface (Stasko, Fischer, Schoenfisch, 2008).

Taite and West (2006) tested the capacity of compound $\mathbf{1 0}$ on the inhibition of platelet adhesion to thrombogenic surfaces. PEG-lys-NO dendrimers (10) reduced platelet adhesion in approximately $81 \%$ regarding to the analogous dendrimer that did not carry NO (PEG-Lys) (Taite, West, 2006). Another assay was performed to verify the ability of compound $\mathbf{1 0}$ on the regulation of vascular cell proliferation (Taite, West, 2006). First, cell viability was assessed using culture of bovine aortic endothelial cells (BAECs) and rat aortic smooth cells (SMSc), which were exposed to NO-releasing dendrimers (10, PEG-Lys-NO) and to ones that do not release NO (PEG-Lys). According to the authors, the NO-releasing dendrimer $\mathbf{1 0}$ is non toxic 
for BAECs ( $100 \pm 1 \%$ of cell viability) and SMCs $(99 \pm$ $3 \%$ of cell viability). The same test performed with PEGLys, resulted in cell viability of $89 \pm 3 \%$ for BAECs and $87 \pm 6 \%$ for SMCs. As reported (Taite, West, 2006) this result showed that even the PEG-Lys low toxicity is reduced when NO is linked to the dendrimer (PEG-Lys-NO, 10). They also demonstrated the ability of compound $\mathbf{1 0}$ to selectively target an inflamed endothelium (compound $\mathbf{1 0}$ modified with a targeting ligand specific for inflamed endothelium - Sialyl Lewis X), as an example of the significant therapeutic potential of such NO-releasing dendrimer.

Johnson et al. (2010) reported the activity of $S$ nitrosothiol dendrimer 9 (G4-SNAP) in reducing ischemia/ reperfusion injury. Using the same concentration of $S$-nitrosothiol ( 2 mM of SNAP) in G4-SNAP and in free SNAP (not attached on dendrimer), the infarct percentage ( $\%$ infarct) was respectively of $3.48 \pm 0.46 \%$ and $4.41 \pm 1.45 \%$ (not statistically different). These values were lower than the exhibited by control (similar molecules that do not delivery NO: G4-NAP and NAP), in which the \% infarct was around $11 \%$ (Johnson et al., 2010).

Acute toxicity of 9 was evaluated on human umbilical vein endothelial cells (HUVEC) and pulmonary artery endothelial cells (CPA-47), using two different assays: propidium iodide uptake (PI) and the release of lactate dehydrogenase $(\mathrm{LDH})$. Results demonstrated the low cytotoxicity of compound $\mathbf{9}$ in two concentrations (4 and $40 \mathrm{mM}$ ) after two hours of exposure: the HUVEC viability was in the range of $89.1-92.7 \%$ and the CPA-47 in the range of $87.7-92.3 \%$ (in both PI and LDH tests) (Johnson et al., 2010).

The same authors (Johnson et al., 2010) also evaluated the kinetics aspects of nitric oxide release from compound $9(300 \mathrm{nM})$ initiated by different concentrations $(10,2,1,0.5 \mathrm{mM})$ of glutathione (GSH). The higher rate for NO release was achieved with $0.5 \mathrm{mM}$ of GSH, resulting in a maximum flux of $1429 \mathrm{ppb} \mathrm{NO} \mathrm{mg}^{-1} \mathrm{~s}^{-1}$ after 45 min. In addition, reperfusion experiments performed with GSH $(0.5 \mathrm{mM})$ and G4-SNAP together (varying the concentration between $23 \mathrm{pM}-31 \mathrm{nM}$ ) resulted in an optimal therapeutic dose of $0.23 \mathrm{nM}$ of G4-SNAP (i.e., $15 \mathrm{nM}$ of SNAP). This result represents a 133 fold lower dose in comparison to the free SNAP optimal dose $(2 \mathrm{mM})$, and led to only $2.34 \pm 0.9 \%$ infarct (Johnson et al., 2010).

Benini, McGarvey and Franco (2008) evaluated the relaxation effects of ruthenium nitrosyl dendrimers (11 and 13) in denuded normotensive rat aortic rings (precontracted with noradrenaline). Slow delayed relaxation started after $15 \min (14.1 \pm 6.2 \%$ induced by compounds 11 and 13, at a concentration of $3 \mathrm{mM}$ of the ruthenium nitrosyl) and the maximum relaxation $(36.8 \pm 6.5 \%)$ was achieved in the second hour. This is on agreement with the behavior observed for [ $\mathrm{Ru}($ edta)NO] in solution, for which the maximal relaxation effect in the second hour was $62.3 \pm$ $16.5 \%$. Compound 11 was also evaluated regarding to its trypanocidal activity in vitro against drug-resistant strain (Y strain) of Trypanosoma cruzi. At the concentration of $1.0 \mathrm{mM}$ (in relation to ruthenium nitrosyl), $100 \%$ of typomastigote forms of the parasite were killed, in comparison to the $89 \%$ of activity exhibited by [Ru(edta)NO] not attached to the dendrimer (Benini, McGarvey, Franco, 2008). The trypanocidal effect was attributed to NO release, once the non NO-releasing complex $\left[\mathrm{Ru}^{\mathrm{III}}\right.$ (edta) $\left.\left(\mathrm{H}_{2} \mathrm{O}\right)\right]^{-}$did not exhibited any activity (Benini, McGarvey, Franco, 2008).

Sun (2012) evaluated the antibacterial activity of compounds 18, 21, 22, 25, 26, 29 (see Figure 6 and Table 1) and each respective precursor (dendrimer without diazeniumdiolate moiety - non NO-releasing dendrimers, described for simplicity as 18a, 21a, 22a, 25a, 26a, 29a) against Pseudomonas aeruginosa (Gram-negative), standard Staphylococcus aureus (Gram-positive) and antibiotic-resistant (methicillin) S. aureus (MRSA). In general, the concentration of NO-releasing dendrimers needed to kill completely $P$. aeruginosa was lower than the one required by the respective non NO-releasing dendrimers. Similar results were observed for Gram-positive $S$. aureus, except for the dendrimer functionalized with $\mathrm{PO}$, in which bactericidal efficacy of compound 22a (non NO-releasing dendrimer) was greater than for 22 (NOreleasing dendrimer). This behavior was attributed to the negative zeta potential ( $\zeta$ ) value for the NO-releasing 22 $(-14.0 \pm 5.4 \mathrm{mV})$ in comparison to the positive value for 22a $(7.1 \pm 0.6 \mathrm{mV})$ (Sun, et al., 2012). Once bacterial membrane is negatively charged, interactions with molecules with more positive $\zeta$ are expected to be enhanced, improving the efficiency of these compounds (Sun et al., 2012). NO-releasing dendrimers $(\mathbf{1 8}, \mathbf{2 1}, \mathbf{2 2}, \mathbf{2 5}, \mathbf{2 6}$, 29) also presented greater bactericidal efficacy against antibiotic-resistant $S$. aureus (MRSA) than the respective non NO-releasing species (18a, 21a, 22a, 25a, 26a, 29a) (Sun et al., 2012). Nitric oxide bactericidal activity was attributed to NO byproducts such as peroxynitrite $\left(\mathrm{ONOO}^{-}\right)$and dinitrogen trioxide $\left(\mathrm{N}_{2} \mathrm{O}_{3}\right)$ which would drive the oxidative and the nitrosative stress (Sun et al., 2012).

The same authors (Sun et al., 2012) also evaluate the antibacterial activity of compounds 18, 21, 22, 25, 26, 29 on respect to the dendrimer size (G2 vs. G5) and exterior functionality (PO, SO and PEG) (Figure 6). In general, dendrimer $\mathrm{G} 5(\mathbf{2 1}, \mathbf{2 5}, \mathbf{2 9})$ were more effective 
than $\mathrm{G} 2(\mathbf{1 8}, \mathbf{2 2}, \mathbf{2 6})$, and this behavior was attributed to the high density of diazeniumdiolates groups, which led to NO release close to the bacteria cells. In respect to the exterior functionality, dendrimer with $\mathrm{SO}$ on the surface (Figure 6) were the most effective, followed by PO and PEG (bacterial activity $\mathrm{SO}>\mathrm{PO}>\mathrm{PEG}$ ) (Sun et al., 2012). Authors attributed this result to the association between the dendrimer surface and the cytoplasmic membrane of the bacteria (negatively charged), which is dependent on hydrophobic and electrostatic interactions, and thus favoring SO groups (more positive zeta potential and hydrophobicity) on the surface of dendrimers relative to PO and PEG (Sun et al., 2012).

According to the data described above, in general, the NO-releasing dendrimers exhibit low cytotoxicity and the biological assays showed that the activity of the different NO-donors was similar or improved after the attachment to dendrimers.

\section{CONCLUSION}

The combination of classical and new NO-donors with different materials allows to expand the field of possible applications for the NO molecule, constituting an attractive therapeutic option. In general these strategies aim to solve the main challenge in NO-donor therapy: release a desired amount of $\mathrm{NO}$ at specific targets.

In this context, dendrimers are molecules which hold interesting properties to be used on the development of NO-carrier systems. The possibility of surface functionalization of dendrimers with one or more molecules of interest can improve biocompatibility, solubility and specificity of these systems, allowing the delivery of nitric oxide to targeted cells or tissues. Furthermore, according to the type of NOdonor conjugated with the dendrimer (metal nitrosyl, diazeniumdiolates, $S$-nitrosothiols and new ones), the mechanism of NO release can be modified to fit a desired situation, like fast and large amount of NO released, or a low and continuous NO flow. Also, the mechanism involved in the nitric oxide release can be chosen according to the purpose, from spontaneous to triggered.

The diverse NO-releasing dendrimers described in this review offers advantages and disadvantages, and exhibit inherent characteristics regarding to the NO-release mechanism. This fact allows the choice of the most appropriate NO-donor dendrimer and acts as a guide for the development of new NO-donors carriers. Also, the diverse biological applications tested so far with NO-releasing dendrimers show the potential uses of this system in different therapies and the new possibilities.
Another aspect that deserves attention is on regard to NO scavengers dendrimers. This topic has only briefly mentioned here as a consequence of a lack of literature on this regard. Certainly, synthetic aspects and biological experiments aiming septic shock control will be quite welcome.

In this context, the use of dendrimers as NO carriers is a quite promising subject of research to be explored.

\section{ACKNOWLEDGMENTS}

The authors acknowledge the Brazilian agencies FAPESP, CAPES and CNPq for the financial support.

\section{REFERENCES}

ARCHUT, A.; AZZELLINI, G.C.; BALZANI, V.; DE COLA, L.; VO1GTLE, F. Toward photoswitchable dendritic hosts. Interaction between azobenzene-functionalized dendrimers and eosin. J. Am. Chem. Soc., v.120, p.12187-12191, 1998.

ASTRUC, D.; BOISSELIER, E.; ORNELAS, C. Dendrimers designed for functions: from physical, photophysical, and supramolecular properties to applications in sensing, catalysis, molecular electronics, photonics, and nanomedicine. Chem. Rev., v.110, p.1857-1959, 2010.

BAYLIS, C. Nitric oxide deficiency in chronic kidney disease. Am. J. Physiol. Renal. Physiol., v.294, p.F1-F9, 2008.

BELL, S.E.; SHAH, C.M.; GORDGE, M.P. Protein disulfideisomerase mediates delivery of nitric oxide redox derivatives into platelets. Biochem. J., v.403, p.283-288, 2007.

BENINI, P.G.Z.; McGARVEY, B.R.; FRANCO, D.W. Functionalization of PAMAM dendrimers with [RuIII(edta) (H2O)]. Nitric Oxide, v.19, p.245-251, 2008.

BOGDAN, C. Nitric oxide and the immune response. Nat. Immunol., v.2, p.907-916, 2001.

BOGDAN, C.; RÖLLINGHOFF, M.; DIEFENBACH, A. The role of nitric oxide in innate immunity. Immunol. Rev., v.173, p.17-26, 2000.

BORGES, S.S.S.; DAVANZO, C.U.; CASTELLANO, E.E.; Z-SCHPECTOR, J.; SILVA, S.C.; FRANCO, D.W. Ruthenium nitrosyl complexes with N-Heterocyclic ligands. Inorg. Chem., v.37, p.2670-2677, 1998. 
BREDT, D.S.; HWANG, P.M.; SNYDER, S.H. Localization of nitric oxide synthase indicating a neural role for nitric oxide. Nature, v.347, p.768-770, 1990.

BUHLEIER, E.; WEHNER, W.; VÖGTLE, F. "Cascade"and "Nonskid-Chain-like" syntheses of molecular cavity topologies. Synthesis, v.2, p.155-158, 1978.

CAMERON, B.R.; DARKES, M.C.; YEE, H.; OLSEN, M.; FRICKER, S.P.; SKERLJ, R.T.; BRIDGER, G.J.; DAVIES, N.A.; WILSON, M.T.; ROSE, D.J.; ZUBIETA, J. Ruthenium (III) polyaminocarboxylate complexes: efficient and effective nitric oxide scavengers. Inorg. Chem., v.42, p.1868-1876, 2003.

CARLMARK, A.; HAWKER, C.; HULTA, A.; MALKOCH, M. New methodologies in the construction of dendritic materials. Chem. Soc. Rev., v.38, p.352-362, 2009.

CARLOS, R.M.; FERRO, A.A.; SILVA, H.A.S.; GOMES, M.G.; BORGES, S.S.S; FORD, P.C.; TFOUNI, E.; FRANCO, D.W. Photochemical reactions of trans- $\left[\mathrm{Ru}\left(\mathrm{NH}_{3}\right)_{4} \mathrm{~L}(\mathrm{NO})\right]^{3+}$ complexes. Inorg. Chim. Acta, v.357, p.1381-1388, 2004.

CHAN, K.L. Role of nitric oxide in ischemia and reperfusion injury. Curr. Med. Chem. - Anti-Inflammatory and AntiAllergy Agents, v.1, p.1-13, 2002.

CIOLKOWSKI, M.; PETERSEN, J.F.; FICKER, M.; JANASZEWSKA, A.; CHRISTENSEN, J.B.; KLAJNERT, B.; BRYSZEWSKA, M. Surface modification of PAMAM dendrimer improves its biocompatibility. Nanomed. Nanotech. Biol. Med., v.8, p.815-817, 2012.

DAVIES, K.M.; WINK, D.A.; SAAVEDRA, J.E.; KEEFER, L.K. Chemistry of the diazeniumdiolates. 2. kinetics and mechanism of dissociation to nitric oxide in aqueous solution. J. Am. Chem. Soc., v.123, p.5473-5481, 2001.

DAVIES, N.A.; WILSON, M.T.; SLADE, E.; FRICKER, S.P.; MURRER, B.A.; POWELL, N.A.; HENDERSON, G.R. Kinetics of nitric oxide scavenging by ruthenium(iii) polyaminocarboxylates: novel therapeutic agents for septic shock. Chem. Commun., v.18, p.47-48, 1997.

DEVARAKONDA, B.; HILL, R.A.; VILLIERS, M.M. The effect of PAMAM dendrimer generation size and surface functional group on the aqueous solubility of nifedipine. Int. J. Pharm., v.284, p.133-140, 2004.
DORO, F.G.; RODRIGUES-FILHO, U.P.; TFOUNI, E. A regenerable ruthenium tetraamine nitrosyl complex immobilized on a modified silica gel surface: Preparation and studies of nitric oxide release and nitrite-to-NO conversion. J. Coll. Interf. Sci., v.307, p.405-417, 2007.

DUFÈS, C.; UCHEGBU, I.F.; SCHÄTZLEIN, A.G. Dendrimers in gene delivery. Adv. Drug Deliv. Rev., v.57, p.2177-2202, 2005.

DUNCAN, R.; IZZO, L. Dendrimer biocompatibility and toxicity. Adv. Drug Deliv. Rev., v.57, p.2215-2237, 2005.

EROY-REVELES, A.A.; MASCHARAK, P.K. Nitric oxidedonating materials and their potential in pharmacological applications for site-specific nitric oxide delivery. Future Med. Chem., v.1, p.1497-1507, 2009.

FLORES-SANTANA, W.; SWITZER, C.; RIDNOUR, L.A.; BASUDHAR, D.; MANCARDI, D.; DONZELLI, S.; THOMAS, D.D.; MIRANDA, K.M.; FUKUTO, J.M.; WINK, D.A. Comparing the Chemical Biology of NO and HNO. Arch. Pharm. Res., v.32, p.1139-1153, 2009.

FRICKER, S.P.; SLADE, E.; POWELL, N.A.; VAUGHAN, O.J.; HENDERSON, G.R.; MURRER, B.A.; MEGSON, I.L.; BISLAND, S.K.; FLITNEY, F.W. Ruthenium complexes as nitric oxide scavengers: a potential therapeutic approach to nitric oxide-mediated diseases. Br. J. Pharmacol., v.122, p.1441-1449, 1997.

FRIEDMAN, A.J.; HAN, G.; NAVATI, M.S.; CHACKO, M.; GUNTHER, L.; ALFIERI, A.; FRIEDMAN, J.M. Sustained release nitric oxide releasing nanoparticles: characterization of a novel delivery platform based on nitrite containing hydrogel/glass composites. Nitric Oxide, v.19, p.12-20, 2008.

FURCHGOTT, R.F.; ZAWADZKI, J.V. The obligatory role of endothelial cells in the relaxation of arterial smooth muscle by acetylcholine. Nature, v.288, p.373-376, 1980.

FUKUTO, J.M.; CARRINGTON, S.J.; TANTILLO, D.J.; HARRISON, J.G.; IGNARRO, L.J.; FREEMAN, B.A.; CHEN, A.; WINK, D.A. Small molecule signaling agents: the integrated chemistry and biochemistry of nitrogen oxides, oxides of carbon, dioxygen, hydrogen sulfide, and their derived species. Chem. Res. Toxicol., v.25, p.769-793, 2012. 
GARTHWAITE, J. Glutamate, nitric oxide and cell-cell signalling in the nervous system. Trends Neurosci., v.14, p.60-67, 1991.

GARTHWAITE, J. Neural nitric oxide signaling. Trends Neurosci., v.18, p51-52, 1995.

GILLIES, E.R.; FRÉCHET, J.M.J. Dendrimers and dendritic polymers in drug delivery. Drug Disc. Today, v.10, p.3543, 2005.

GOMES, M.G.; DAVANZO, C.U.; SILVA, S.C.; LOPES, L.G.F; SANTOS, P.S.; FRANCO, D.W. Cis- and trans-nitrosylt etraammineruthenium(II). Spectral and electrochemical properties and reactivity. J. Chem. Soc., Dalton Trans., p.601-607, 1998.

GUEDES, P.M.M.; OLIVEIRA, F.S.; GUTIERREZ, F.R.S.; SILVA, G.K.; RODRIGUES, G.J.; BENDHACK, L.M.; FRANCO, D.W.; MATTA, M.A.V.; ZAMBONI, D.S.; SILVA, R.S.; SILVA, J.S. Nitric oxide donor trans$\left[\mathrm{RuCl}\left([15] \mathrm{aneN}_{4}\right) \mathrm{NO}^{2+}\right.$ as a possible therapeutic approach for chagas' disease. Br. J. Pharmacol., v.160, p.270-282, 2010 .

HOGG, N. Biological chemistry and clinical potential of S-nitrosothiols. Free Radic. Biol. Med., v.28, p.1478-1486, 2000 .

HU, C.M.; KANG, J.J.; LEE, C.C.; LI, C.H.; LIAO, J.W.; CHENG, Y.W. Induction of vasorelaxation through activation of nitric oxide synthase in endothelial cells by brazilin. Eur. J. Pharmacol., v.468, p.37-45, 2003.

HRABIE, J.A.; KEEFER, L.K. Chemistry of the nitric oxidereleasing diazeniumdiolate ("Nitrosohydroxylamine") functional group and its oxygen-substituted derivatives. Chem. Rev., v.102, p.1135-1154, 2002.

IGNARRO, L.J. Biosynthesis and metabolism of endotheliumderived nitric oxide. Annu. Rev. Pharmacol. Toxicol., v.30, p.535-560, 1990.

JEN, M.C.; SERRANO, M.C.; LITH, R.V.; AMEER, G.A. Polymer-based nitric oxide therapies: recent insights for biomedical applications. Adv. Funct. Mater., v.22, p.239$260,2012$.
JOHNSON, T.A.; STASKO, N.A.; MATTHEWS, J.L.; CASCIO, W.E.; HOLMUHAMEDOV, E.L.; JOHNSON, C.B.; SCHOENFISCH, M.H. Reduced ischemia/reperfusion injury via glutathione-initiated nitric oxide-releasing dendrimers. Nitric Oxide, v.22, p.30-36, 2010.

KARPUZOGLU, E.; AHMED, S.A. Estrogen regulation of nitric oxide and inducible nitric oxide synthase (iNOS) in immune cells: Implications for immunity, autoimmune diseases, and apoptosis. Nitric Oxide, v.15, p.177-186, 2006.

KEEFER, L.K. Fifty years of diazeniumdiolate research. From laboratory curiosity to broad-spectrum biomedical advances. ACS Chem. Biol., v.6, p.1147-1155, 2011.

KIM, T-I.; BAEK, J-U; BAI, C.Z.; PARK, J-S. Arginineconjugated polypropylenimine dendrimer as a non-toxic and efficient gene delivery carrier. Biomaterials, v.28, p.2061-2067, 2007.

KOBAYASHI, H.; KAWAMOTO, S.; JO, S-K.; BRYANT JR, H.L.; BRECHBIEL, M.W.; STAR, R.A. Macromolecular MRI contrast agents with small dendrimers: pharmacokinetic differences between sizes and cores. Bioconjugate Chem., v.14, p.388-394, 2003.

KOJIMA, C.; TURKBEY, B.; OGAWA, M.; BERNARDO, M.; REGINO, C.A.S.; BRYANT JR, L.H.; CHOYKE, P.L.; KONO, K.; KOBAYASHI, H. Dendrimer-based MRI contrast agents: the effects of PEGylation on relaxivity and pharmacokinetics. Nanomed. Nanotechol. Biol. Med., v.7, p.1001-1008, 2011.

LU, Y.; SUN, B.; LI, C.; SCHOENFISCH, M.H. Structurally diverse nitric oxide-releasing poly(propylene imine) dendrimers. Chem. Mater, v.23, p.4227-4233, 2011.

LUIKING, Y.C.; ENGELEN, M.P.K.J.; DEUTZ, N.E.P. Regulation of nitric oxide production in health and disease. Curr. Opin. Clin. Nutr. Metab. Care., v.13, p.97-104, 2010.

MARGERUM, L.D.; CAMPION, B.K.; KOO, M.; SHARGILL, N.; LAI, J-J.; MARUMOTO, A.; SONTUM, P.C. Gadolinium(III) DO3A macrocycles and polyethylene glycol coupled to dendrimers: effect of molecular weight on physical and biological properties of macromolecular magnetic resonance imaging contrast agents. J. Alloys Compd., v.249, p.185-190, 1997. 
MEDINA, S.H.; EL-SAYED, M.E.H. Dendrimers as carriers for delivery of chemotherapeutic agents. Chem. Rev., v.109, p.3141-3157, 2009.

MENJOGE, A.R.; RINDERKNECHT, A.L.; NAVATH, R.S.; FARIDNIA, M.; KIM, C.J., ROMERO, R.; MILLER, R.K.; KANNAN, R.M. Transfer of PAMAM dendrimers across human placenta: Prospects of its use as drug carrier during pregnancy. J. Control. Rel., v.150, p.326-338, 2011.

METZKER, G.; CARDOSO, D.R.; FRANCO, D.W. Reaction of ruthenium nitrosyl complexes with superoxide. Polyhedron, v.50, p.328-332, 2013.

MILLER, M.R.; MEGSON, I.L. Recent developments in nitric oxide donor drugs. Br. J. Pharmacol., v.151, p.305-321, 2007.

MINTZER, M.A.; GRINSTAFF, M.W. Biomedical applications of dendrimers: a tutorial. Chem. Soc. Rev., v.40, p.173-190, 2011.

MINTZER, M.A.; SIMANEK, E.E. Nonviral vectors for gene delivery. Chem. Rev., v.109, p.259-302, 2009.

MONCADA, S.; PALMER, R.M.J.; HIGGS, E.A. Nitric oxide: physiology, pathophysiology and pharmacology. Pharmacol. Rev., v.43, p.109-142, 1991.

NAM, H.Y.; NAM, K.; LEE, M.; KIM, S.W.; BULL, D.A. Dendrimer type bio-reducible polymer for efficient gene delivery. J. Control. Rel., v.160, p.592-600, 2012.

NEWKOME, G.R.; SHREINER, C.D. Poly(amidoamine), polypropylenimine, and related dendrimers and dendrons possessing different $1 \rightarrow 2$ branching motifs: an overview of the divergent procedures. Polymer, v.49, p.1-173, 2009.

NEWKOME, G.R.; YAO, Z.; BAKER, G.R.; GUPTA, V.K. Micelles. Part 1. Cascade molecules: a new approach to micelles. A [27]-arborol. J. Org. Chem., v.50, p.2003-2004, 1985.

NANJWADE, B.K.; BECHRA, H.M.; DERKARA, G.K.; MANVI, F.V.; NANJWADE, V.K. Dendrimers: Emerging polymers for drug-delivery systems. Eur. J. Pharm. Sci., v.38, p.185-196, 2009.
OSTI, R.Z.; SERRANO, F.A.; PASCHOALIN, T.; MASSAOKA, M.H.S.; TRAVASSOS, L.R.; TRUZZI, D.R.; RODRIGUES, E.G.; FRANCO, D.W. The in vitro and in vivo antitumour activities of nitrosyl ruthenium amine complexes. Aust. J. Chem., v.65, p.1333-1341, 2012.

PACHER, P.; BECKMAN, J.S.; LIAUDET, L. Nitric oxide and peroxynitrite in health and disease. Physiol. Rev., v.87, p.315-424, 2007.

PAGLIARO, P. Differential biological effects of products of nitric oxide (NO) synthase: it is not enough to say NO. Life Sci., v.73, p.2137-2149, 2003.

PALMER, R.M.; ASHTON, D.S.; MONCADA, S. Vascular endothelial cells synthesize nitric oxide from L-arginine. Nature, v.333, p.664-666, 1998.

PEREIRA, J.C.M.; CARREGARO, V.; COSTA, D.L.; SILVA, J.S.; CUNHA, F.Q.; FRANCO, D.W. Antileishmanial activity of ruthenium(II)tetraammine nitrosyl complexes. Eur. J. Med. Chem., v.45, p.4180-4187, 2010.

REID, M.B. Invited review: redox modulation of skeletal muscle contraction: what we know and what we don't. J. Appl. Physiol., v.90, p.724-731, 2001.

RICCIO, D.A.; SCHOENFISCH, M.H. Nitric oxide release: part I. Macromolecular scaffolds. Chem. Soc. Rev., v.41, p.3731-3741, 2012.

SADEKAR, S.; GHANDEHARI, H. Transepithelial transport and toxicity of PAMAM dendrimers: implications for oral drug delivery. Adv. Drug Deliv. Rev., v.64, p.571-588, 2012.

SARAIVA, J.; MAROTTA-OLIVEIRA, S.S.; CICILLINI, S.A.; ELOY, J.O.; MARCHETTI, J.M. Nanocarriers for nitric oxide delivery. J. Drug Deliv., v.2011, p.1-16, 2011.

SCHULZ, R.; KELM, M.; HEUSCH, G. Nitric oxide in myocardial ischemia/reperfusion injury. Cardiovasc. Res., v.61, p.402-413, 2004.

SEABRA, A.B.; DURÁN, N. Nitric oxide-releasing vehicles for biomedical applications. J. Mater. Chem., v.20, p.16241637, 2010.

SERAFIM, R.A.M.; PRIMI, M.C.; TROSSINI, G.H.G.; FERREIRA, E.I. Nitric oxide: state of the art in drug design. Curr. Med. Chem, v.19, p.386-405, 2012. 
SHCHARBIN, D.G.; KLAJNERT, B.; BRYSZEWSKA, M. Dendrimers in gene transfection. Biochemistry (Moscow), v.74, p.1070-1079, 2009.

SILVA, J.J.; OSAKABE, A.L.; PAVANELLI, W.R.; SILVA, J.S.; FRANCO, D.W. In vitro and in vivo antiproliferative and trypanocidal activities of ruthenium NO donors. Br. J. Pharmacol., v.152, p.112-121, 2007.

SILVA, J.J.; PAVANELLI, W.R.; PEREIRA, J.C.; SILVA, J.S.; FRANCO, D.W. Experimental chemotherapy against Trypanosoma cruzi infection using ruthenium NO donors. Antimicrobial. Agents Chem., v.53, p.4414-4421, 2009.

STASKO, N.A.; SCHOENFISCH, M.H. Dendrimers as a scaffold for nitric oxide release. J. Am. Chem. Soc., v.128, p.8265-8271, 2006.

STAMLER, J.S.; MEISSNER, G. Physiology of nitric oxide in skeletal muscle. Physiol. Rev., v.81, p.209-237, 2001.

STASKO, N.A.; FISCHER, T.H.; SCHOENFISCH, M.H. $S$-Nitrosothiol-modified dendrimers. Biomacromolecules, v.9, p.834-841, 2008.

STEINERT, J.R.; CHERNOVA, T.; FORSYTHE, I.D. Nitric oxide signaling in brain function, dysfunction, and dementia. Neuroscientist, v.16, p.435-52, 2010.

SUN, B.; SLOMBERG, D.L.; CHUDASAMA, S.L.; LU, Y.; SCHOENFISCH, M.H. Nitric oxide-releasing dendrimers as antibacterial agents. Biomacromolecules, v.13, p.33433354, 2012.

SUN, M.; FAN, A.; WANG, Z.; ZHAO, Y. Dendrimer-mediated drug delivery to the skin. Soft Matter, v.8, p.4301-4305, 2012.

TAITE, L.J.; WEST, J.L. Poly(ethylene glycol)-lysine dendrimers for targeted delivery of nitric oxide. J. Biomater. Sci. Polymer Edn, v.17, p.1159-1172, 2006.

TANG, J.; SHENG, Y.; HU, H.; SHEN, Y. Macromolecular MRI contrast agents: structures, properties and applications. Prog. Polym. Sci., v.38, p.462-502, 2013.

TFOUNI, E.; DORO, F.G.; GOMES, A.J.; SILVA, R.S.; METZKER, G.; BENINI, P.G.Z; FRANCO, D.W. Immobilized ruthenium complexes and aspects of their reactivity. Coord. Chem. Rev., v.254, p.355-371, 2010.
TFOUNI, E.; KRIEGER, M.; McGARVEY, B.R.; FRANCO, D.W. Structure, chemical and photochemical reactivity and biological activity of some ruthenium amine nitrosyl complexes. Coord. Chem. Rev., v.236, p.57-69, 2003.

TFOUNI, E., TRUZZI, D.R.; TAVARES, A.; GOMES, A.J.; FIGUEIREDO, L.E.; FRANCO, D.W. Biological activity of ruthenium nitrosyl complexes. Nitric Oxide, v.26, p.38$53,2012$.

THOMAS, D.D.; LIU, X.; KANTROW, S.P.; LANCASTER, J.R. The biological lifetime of nitric oxide: implications for the perivascular dynamics of $\mathrm{NO}$ and $\mathrm{O}_{2}$. Proc. Natl. Acad. Sci., v.98, p.355-360, 2001.

TOLEDO, J.C.; AUGUTSO, O. Connecting the chemical and biological properties of nitric oxide. Chem. Res. Toxicol., v.25, p.975-989, 2012.

TOLEDO, J.C.; SILVA, H.A.S.; SCARPELLINI, M.; MORI, V.; CAMARGO, A.J.; BERTOTTI, M; FRANCO, D.W. Ruthenium tetraammines as a model of nitric oxide donor compounds. Eur. J. Inorg. Chem., v.9, p.1879-1885, 2004.

TOLEDO, J.C.; LOPES, L.G.F.; ALVES, A.A.; SILVA, L.P.; FRANCO, D.W. Release of NO by a nitrosyl complex upon activation by the mitochondrial reducing power. J. Inorg. Biochem., v.89, p.267-271, 2002.

TOMALIA, D.A.; BAKER, H.; DEWALD, J.; HALL, M.; KALLOS, G.; MARTIN, S.; ROECK, J.; RYDER, J.; SMITH, P. A new class of polymers: starburst-dendritic macromolecules. Polym. J., v.17, p.117-132, 1985.

VÖGTLE, F.; PLEVOETS, M.; NIEGER, M.; AZZELLINI, G.C.; CREDI, A.; DE COLA, L.; DE MARCHIS, V.; VENTURI, M.; BALZANI, V. Dendrimers with a photoactive and redox-active $\left[\mathrm{Ru}(\mathrm{bpy})_{3}\right]^{2+}$-Type core: photophysical properties, electrochemical behavior, and excited-state electron-transfer reactions. J. Am. Chem. Soc., v.121, p.6290-6298, 1999.

WALSH, G.M.; LEANE, D.; MORAN, N.; KEYES, T.E.; FORSTER, R.J.; KENNY, D.; O’NEILL, S. S-Nitrosylation of platelet $\alpha \operatorname{IIb} \beta 3$ as revealed by raman spectroscopy. Biochemistry, v.46, p.6429-6436, 2007. 
WANAT, A.; SCHNEPPENSIEPER, T.; KAROCKI, A.; STOCHEL, G.; ELDIK, R.V. Thermodynamics and kinetics of RuIII(edta) as an efficient scavenger for nitric oxide in aqueous solution. J. Chem. Soc., Dalton Trans., v.6, p.941950, 2002.

WANG, P.G.; XIAN, M.; TANG, X.; WU, X.; WEN, Z.; CAI, T.; JANCZUK, A.J. Nitric oxide donors: chemical activities and biological applications. Chem. Rev., v.102, p.10911134, 2002.

WEBB, A.; BOND, R.; McLEAN, P.; UPPAL, R.; BENJAMIN, N.; AHLUWALIA, A. Reduction of nitrite to nitric oxide during ischemia protects against myocardial ischemiareperfusion damage. Proc. Natl. Acad. Sci., v.101, p.1368313688, 2004.

WIENER, E.C.; BRECHBIEL, M.W.; BROTHERS, H.; MAGIN, R.L; GANSOW, O.A.; TOMALIA, D.A.; LAUTERBUR, P.C. Dendrimer-based metal chelates: a new class of magnetic resonance imaging contrast agents. Magn. Reson. Med., v.31, p.1-8, 1994.

WIJAGKANALAN, W.; KAWAKAMI, S.; HASHIDA, M. Designing dendrimers for drug delivery and imaging: pharmacokinetic considerations. Pharm. Res., v.28, p.15001519, 2011.
YANG, W.; CHENG, Y.; XU, T.; WANG, X. WEN, L-P. Targeting cancer cells with biotinedendrimer conjugates. Eur. J. Med. Chem., v.44, p.862-868, 2009.

YETIK-ANACAK, G.; CATRAVAS, J.D. Nitric oxide and the endothelium: history and impact on cardiovascular disease. Vascul. Pharmacol., v.45, p.268-276, 2006.

ZANICHELLI, P.G.; MIOTTO, A.M.; ESTRELA, H.F.G.; SOARES, F.R.; GRASSI-KASSISSE, D.M.; SPADARIBRATFISCH, R.C.; CASTELLANO, E.E.; RONCAROLI, F.; PARISE, A.R.; OLABE, J.A.; BRITO, A.R.M.S.; FRANCO, D.W. The $[\mathrm{Ru}(\mathrm{Hedta}) \mathrm{NO}]^{0,1-}$ system: structure, chemical reactivity and biological assays. J. Inorg. Biochem., v.98, p.1921-1932, 2004.

ZANICHELLI, P.G.; SERNAGLIA, R.L.; FRANCO, D.W. Immobilization of the [RuII(edta) $\left.\mathrm{NO}^{+}\right]$ion on the surface of functionalized silica gel. Langmuir, v.22, p.203-208, 2006.

ZHOU, L.; ZHU, D-Y. Neuronal nitric oxide synthase: structure, subcellular localization, regulation, and clinical implications. Nitric Oxide, v.20, p.223-230, 2009.

ZWEIER, J.L.; WANG, P.H.; SAMOUILOV, A.; KUPPUSAMY, P. Enzyme independent formation of nitric-oxide in biological tissues. Nat. Med., v.1, p.804-809, 1995. 